\title{
Manifestasi Penyakit Kulit pada Pasien Diabetes Melitus Tipe 2 di Rumah Sakit Dr. Pirngadi Medan
}

\author{
Dione Larissa ${ }^{1}$, Kristo Nababan ${ }^{2}$, Joseph Sibarani ${ }^{3}$ \\ ${ }^{1}$ Mahasiswa Fakultas Kedokteran Universitas HKBP Nommensen \\ 2 Departemen Kesehatan Kulit dan Kelamin Fakultas Kedokteran Universitas HKBP Nommensen \\ ${ }^{3}$ Departemen Penyakit Dalam Fakultas Kedokteran Universitas HKBP Nommensen \\ Korespondensi: Masdiwani Noviana, Email: masdiwani.noviana@yahoo.com
}

\begin{abstract}
Background: Diabetes mellitus (DM) is a metabolic group with characteristic hyperglycemia that occurs due to abnormal insulin secretion, insulin action, or both. DM is often called the silent killer because the patients know they has DM only after the patient experiencing complications and manifestations. It is estimated that $30-70 \%$ of DM patients experience skin manifestations during the disease process. The relationship between the appearance of skin manifestations with diabetes mellitus is not yet known, but it is suspected due to chronic hyperglycemia and abnormalities of the immune system.
\end{abstract}

Objective: To determine skin diseases in patients with type 2 diabetes at General Hospital Dr. Pirngadi Medan.

Methods: This research was a descriptive study with a cross-sectional study design conducted at Dr. General Hospital Pirngadi Medan. Data collection was carried out through 29 medical records of patients with diabetes mellitus from January 2018 to December 2018. Samples were selected by total sampling.

Results: From 29 samples studied, there were six types of skin manifestations. The most common skin manifestations are Diabetic Ulcer (62.07\%), followed by Steven Johnson Syndrome and diabetic gangrene, which both are equally $13.80 \%$. The other skin manifestations are herpes zoster, gluteal abscess, and bullous pemphigoid (3.44\%).

Conclusion: The most common manifestation of the skin in patients with type $2 \mathrm{DM}$ is Diabetic Ulcer.

Keywords: diabetes mellitus, skin manifestations

\begin{abstract}
Abstrak
Latar belakang: Diabetes melitus (DM) merupakan suatu kelompok metabolik dengan karakteristik hiperglikemia yang terjadi karena kelainan sekresi insulin, kerja insulin, atau kedua-duanya. DM sering disebut silent killer disebabkan karena pasien baru menyadari dia terkena DM setelah mengalami komplikasi maupun manifestasi dari DM itu sendiri. Diperkirakan 30-70\% pasien DM mengalami manifestasi kulit selama proses penyakit berlangsung. Belum diketahui dengan pasti hubungan antara timbulnya manifestasi kulit dengan diabetes melitus, tetapi diduga karena hiperglikemia kronik dan abnormalitas sistem imun.
\end{abstract}

Tujuan: Untuk mengetahui jenis-jenis penyakit kulit pada penderita DM tipe 2 di Rumah Sakit Umum Daerah Dr. Pirngadi Medan.

Metode: Penelitian ini merupakan penelitian deskriptif dengan desain penelitian cross-sectional yang dilakukan di Rumah Sakit Umum Dr. Pirngadi Medan. Pengumpulan data dilakukan melalui rekam medik dengan jumlah 29 data rekam medik penderita DM sejak Januari 2018 sampai Desember 2018. Sampel dipilih dengan teknik total sampling.

Hasil: Dari 29 sampel yang diteliti diperoleh 6 jenis manifestasi kulit. Manifestasi kulit yang paling sering terjadi adalah Ulkus Diabetikum, yaitu sebesar 62.07\%, kemudian Steven Johnson Syndrome dan gangren diabetikum 
masing-masing sebesar 13.8\%. Manifestasi kulit lainnya adalah herpes zooster, abses gluteal dan pemfigoid bulosa sebesar $3.44 \%$.

Kesimpulan: Manifestasi kulit pada penderita DM tipe 2 yang paling sering terjadi adalah Ulkus Dibetikum.

Kata Kunci: diabetes melitus, manifestasi kulit

\section{Pendahuluan}

Diabetes melitus (DM) merupakan suatu kelompok metabolik dengan karakteristik hiperglikemia yang terjadi karena kelainan sekresi insulin, kerja insulin, atau kedua-duanya. ${ }^{1} \mathrm{DM}$ terjadi ketika pankreas memproduksi insulin sangat sedikit atau tubuh tidak mampu menggunakan insulin yang dihasilkan tubuh dengan baik. Insulin merupakan hormon yang berfungsi untuk mengatur gula darah. Efek samping dari gula darah yang tidak terkontrol dari waktu ke waktu akan menyebabkan hiperglikemia. ${ }^{2}$ Epidemiologi penderita DM menurut World Health Organization (WHO) sangat meningkat di tahun yang akan datang. Di Indonesia, diperkirakan akan meningkat dari 8,4 juta pada tahun 2000 menjadi 21,3 juta pada tahun 2030 yang akan datang. ${ }^{3}$ Sedangkan di Sumatra Utara sebanyak 2,4\% pada tahun $2013 .{ }^{4}$

Gejala dari hiperglikemia dapat berupa poliuria, polidipsia, penurunan berat badan, kadang-kadang dengan polifagia, dan penglihatan kabur. Hiperglikemia kronis dapat menyebabkan kerentanan terhadap infeksi tertentu. Sebaliknya, pada hiperglikemia akut, pada pasien yang mengalami diabetes yang tidak terkontrol adalah hiperglikemia dengan ketoasidosis atau sindrom hiperosmolar non-ketotik. Kebanyakan pasien DM mengalami obesitas, dan obesitas itu sendiri menyebabkan beberapa derajat resistensi insulin. Pasien yang tidak obesitas dengan kriteria berat badan normal mungkin memiliki persentase peningkatan lemak tubuh didistribusikan terutama di daerah perut. ${ }^{5}$

Diabetes Melitus sering disebut silent killer. Hal tersebut disebabkan karena pasien baru menyadari dia terkena DM setelah mengalami komplikasi maupun manifestasi dari DM itu sendiri. Pada sebagian besar dari pasien DM tidak terlalu atau bahkan tidak memperhatikan sama sekali perawatan kesehatan dirinya sendiri ditambah lagi dengan lamanya DM tersebut terdiagnosis. Padahal komplikasi DM sebenarnya sudah muncul sejak dini bahkan sejak sebelum diagnosis ditegakkan atau terdeteksi. Sementara jika penanganan sejak dini telah dilakukan, maka bisa membantu memperbaiki kualitas hidup pasien. Penelitian yang dilakukan oleh Callen, dijumpai sebanyak 30\% - 70\% dari jumlah pasien dengan DM dan yang telah terdeteksi adanya manifestasi kulit selama perjalanan penyakit ini dipengaruhi oleh mikrovaskular kulit pada DM. ${ }^{6}$ Pada penelitian yang dilakukan oleh Lider Olmen pada tahun 2011, di Rumah Sakit HJ. Adam Malik Medan, ditemukan 31 jenis penyakit kulit yang timbul akibat dari DM. ${ }^{7}$

Tujuan dari penelitian ini adalah untuk mengetahui jenis-jenis penyakit kulit pada penderita DM tipe 2 di Rumah Sakit Umum Daerah Dr. Pirngadi Medan 2 berdasarkan jenis kelamin dan usia, dan untuk mengetahui lamanya pasien menderita DM hingga timbulnya manifestasi pada kulit.

\section{Metode}

Penelitian ini menggunakan penelitian deskriptif dengan desain cross sectional yang dilakukan di RSUD Dr. Pirngadi Medan.
Sampel pada penelitian ini diambil dengan menggunakan teknik total sampling yaitu pengambilan sampel seluruhnya dari data rekam medis pasien yang sudah di diagnosis DM tipe 2 baik pasien yang pernah di rawat inap maupun rawat jalan dan yang mengalami manifestasi kulit di RSUD Dr. Pirngadi Medan tahun 2018.

\section{Pembahasan}

Perbandingan sampel berdasarkan jenis kelamin pada penelitian ini tidak begitu berarti.namun, pada penelitian yang telah dilakukan oleh Fitri pada tahun 2018, didapati penderita DM tipe 2 lebih banyak dijumpai pada perempuan. ${ }^{8}$ Franck pada tahun 2018 menyatakan belum bisa dipastikan penderita DM lebih banyak pada perempuan ataupun laki-laki. Namun faktor keturunan bisa menjadi salah satu pemicu sehingga DM lebih banyak di derita pada laki-laki. Jika seorang ayah ataupun ibu yang memiliki riwayat DM sebelumnya, maka anak laki-laki mereka akan memiliki peluang yang cukup besar untuk menderita DM juga. Selain itu, pada penelitian juga menyebutkan bahwa perempuan memiliki siklus haid pada tiap bulannya. Sehingga terjadi regenerasi pada tubuh. ${ }^{9}$

Tabel 1. Distribusi sampel berdasarkan jenis kelamin

\begin{tabular}{lcc}
\hline Jenis Kelamin & Jumlah & $\%$ \\
\hline Laki - Laki & 14 & 48,28 \\
Perempuan & 15 & 51,72 \\
\hline Total & 29 & 100 \\
\hline
\end{tabular}

Tabel 2. Distribusi sampel berdasarkan usia

\begin{tabular}{lcc}
\hline Usia (Tahun) & Jumlah & $\%$ \\
\hline $21-40$ & 3 & 10,34 \\
$41-60$ & 16 & 55,17 \\
$61-80$ & 8 & 27,60 \\
$>80$ & 2 & 6,89 \\
\hline Total & 29 & 100 \\
\hline
\end{tabular}

Tabel 3. Distribusi sampel berdasarkan lamanya menderita DM

\begin{tabular}{lcc}
\hline Lama (Tahun) & Jumlah & $\%$ \\
\hline$<5$ & 12 & 41,37 \\
$5-10$ & 13 & 44,83 \\
$>10$ & 4 & 13,80 \\
\hline Total & 29 & 100 \\
\hline
\end{tabular}

Penelitian yang dilakukan oleh Wicaksana (2011) menyatakan bahwa, orang yang berusia $\geq 45$ tahun lebih berisiko terkena DM dibandingkan dengan orang berusia $<45$ tahun. Hal tersebut disebabkan oleh karena faktor degeneratif yaitu menurunnya fungsi tubuh untuk memetabolisme glukosa. Dengan kata lain, tingkat kerentanan terjadinya penyakit DM tipe-2 sejalan dengan 
bertambahnya umur. ${ }^{10}$ Penelitian yang dilakukan oleh Lider pada tahun 2011 lama menderita DM sehingga dijumpainya manifestasi penyakit kulit adalah dibawah 5 tahun. ${ }^{7}$ Sedangkan pada penelitian ini, paling banyak dijumpai manifestasi penyakit kulit pada penderita DM adalah 5-10 tahun seperti pada penelitian yang dilakukan oleh Yasmeen pada tahun 2006. Semakin lama pasien mengetahui dia terkena DM, yang menyebabkan terkena penyakit kulit. Karena jika pasien cepat mengetahui dia terkena DM, maka dia akan mengontrol kadar gula darahnya sehingga sangat kecil kemungkinan timbulnya manifestasi pada kulit. ${ }^{11}$

Tabel 4. Distribusi sampel berdasarkan manifestasi kulit pada pasien Diabetes Melitus

\begin{tabular}{lcc}
\hline Kelainan Kulit & Jumlah & $\%$ \\
\hline Ulkus Diabetikum & 18 & 62,08 \\
Steven Jhonson Syndrom & 4 & 13,80 \\
Herpes Zooster & 1 & 3,44 \\
Gangren Diabetikum & 4 & 13,80 \\
Abses Gluteal & 1 & 3,44 \\
Pemfigoid Bulosa & 1 & 3,44 \\
\hline Total & 29 & 100 \\
\hline
\end{tabular}

Penelitian yang dilakukan oleh Tesfamichal, dkk pada tahun 2016 menyatakan bahwa tingkat kejadian ulkus diabetikum pada penderita DM tipe 2 sangat tinggi. Salah satu yang menyebabkannya adalah karena tingginya kadar gula dalam darah, sehingga pembuluh darah pada kaki mnenjadi sangat mudah terinfeksi mengingat kaki berada dekat dengan sumber kuman. Selain itu, pada penelitian tersebut menyatakan ulkus diabetikum paling banyak di jumpai pada petani yang tinggal di pedesaan yang kemungkinan tingkat pengetahuan akan komplikasi dan cara perawatan terhadap diri masih sangatlah rendah. ${ }^{12}$

\section{Kesimpulan}

Manifestasi penyakit kulit pada penderita DM Tipe 2 yang paling banyak dijumpai adalah ulkus diabetikum dan yang jarang terjadi adalah herpes zoster, abses gluteal dan pemfigoid bulosa. Mayoritas penderita DM Tipe 2 paling banyak dijumpai berjenis kelamin perempuan, dan berusia 41-60 tahun. Rerata pasien mendapatkan manifestasi penyakit kulit setelah menderita DM Tipe 2 selama 5-10 tahun.

\section{Daftar Pustaka}

1. Purnamasari D. Diagnosis dan Klasifikasi Diabetes Melitus. In: IImu Penyakit Dalam. Edisi VI. Jakarta: Interna Publishing; 2014. p. 2325-37.

2. World Health Organisation. Diabetes [Internet]. 2016 [cited 2019 Jul 19]. p. 90-1. Available from: http://www.who.int/mediacentre/factsheets/fs312/en/

3. Galdeano F, Zaccaria S, Parra V, Giannini ME, Salomón S. Cutaneous manifestations of diabetes mellitus: clinical meaning. Dermatología Argentina [Internet]. 2013;16(2010):117-21. Available from: http://www.dermatolarg.org.ar/index.php/dermatolarg/article/viewArticle/10 93

4. Kemkes RI. Situasi dan Analisis Diabetes. Jakarta; 2014.

5. American Diabetes Association. Diagnosis and Classification of Diabetes Mellitus. Diabetes Care [Internet]. 2014 Jan 1 [cited 2019 Sep 2];37 Suppl 1(Supplement 1):81-90. Available from: http://www.ncbi.nlm.nih.gov/pubmed/24357215

6. Callen JP. Dermatological signs of internal disease. Saunders; 2009. p. 199-197.

7. Olmen L. Manifestasi penyakit kulit pada pasien diabetes melitus di Rumah Sakit Umum Pusat Haji Adam Malik Medan periode Juni 2008 sampai Juni 2011. Universitas Sumatra Utara; 2011.

8. Fitri N. Karakteristik penderita diabetes melitus tipe 2 dengan komplikasi yang rawat inap di Rumah Sakit Santa Elisabeth Medan Tahun 2016. Universitas Sumatra Utara; 2018.

9. Franck M. Gender differences in glucose homeostasis and diabetes. Physiol Behav. 2018 Apr; 187: 20-3.

10. Putro R. Faktor-faktor yang berhubungan dengan kejadian diabetes melitus tipe 2. Universitas Diponegoro; 2011.

11. Yasmeen J, Gupta V. Cutaneum manifestations of diabetes mellitus. Vol. 26, International Journal of Dermatology. India; 2006.

12. Tesfamichael $G$, Abebaw A. Prevalence of diabetic foot ulcer and associated factors among adult diabetic patients who attend the diabetic follow-up clinic at the University of Gondar Referral Hospital, North West Ethiopia. Diabetes Res Clin Pract. 2016;1-18. 